\title{
Factors Affecting Adoption of Chemical Fertilizer by Smallholder Farmers in Guto Gida District, Oromia Regional State, Ethiopia
}

\author{
Negera Eba and Getachew Bashargo
}

\author{
Department of Economics, College of Business and Economics, Wollega University, Post Box No: 395, \\ Nekemte, Ethiopia
}

\begin{abstract}
There is a general consensus that fertilizer is considered as one of the most important inputs for the achievement of increased agricultural production and productivity in Ethiopia particularly in the study area. Low production and productivity, which are mainly associated with limited by supply of fertilizer technology, lack of awareness about the importance of fertilizer, lack of knowledge and capacity, lack of sustain training on the adoption of agricultural technology program, inadequate cash or credit from adopting the fertilizer technology. Thus, adoption of fertilizer technology is one of the most promising ways to increase productivity and production of those small household farmers in the study area. The aim of this study was to empirically examine factors affecting adoption and intensity us of fertilizer technology in the study area. The study was based on data collected from a sample of 350 households drawn from Guto Gida District. Data analysis was done with the help of descriptive analysis and econometrics models mainly Probit and Tobit to examine factors influencing the adoption and intensity use of fertilizer in the study area, respectively. Econometric estimation results depicted that education, family size, extension contact, access to information, access to credit, farm income and off-farm activity were positively influenced the adoption of fertilizer whereas distance to market and livestocks are negatively influenced adoption of fertilizer use at standard significant levels. On the other hand, off-farm activity, access to information, landholding size and farming experience are positively affected the intensity use of fertilizer while family size and lives tocks are negatively determined the extent use of fertilizer. Therefore, policy development interventions should give emphasis to improvement of such institutional support systems like FTC (Farmers Training Center, etc) to increase adoption and intensity use of fertilizer to enhance the production and productivity of those small household farmers in the study area.
\end{abstract}

Copyright@2014 STAR Journal. All Rights Reserved.

\section{Article Information}

Article History:

Received : 28-02-2014

Revised : 15-06-2014

Accepted : 20-06-2014

Keywords:

Adoption, Fertilizer

Guto Gida District

Production

Smallholder farmers

${ }^{\star}$ Corresponding Author:

Getachew Bashargo

E-mail:

getabashargo@yahoo.com

\section{INTRODUCTION}

Agriculture continues to be a fundamental instrument for sustainable development, poverty reduction and enhanced food security in developing countries. It is a vital development tool for achieving the Millennium Development Goals (MDG), one of which is to half by 2015 the share of people suffering from extreme poverty and hunger (World Bank, 2008).

In Africa, agriculture is a strong option for spurring growth, overcoming poverty, and enhancing food security. Agricultural productivity growth is also vital for stimulating growth in other sectors of the economy. Thus, one of the fundamental ways of improving agricultural productivity is through the introduction and use of improved agricultural technologies (World Bank, 2008).

As noted by Duflo et al., (2006), the rapid population growth has made Africa to be no longer viewed as a landabundant region where food crop supply could be increased by expansion of land used in agriculture. Large areas in Africa are increasingly becoming marginal for agriculture and arable land has become scarce in many African countries. This makes the need for intensification of land use through use of productivity enhancing technologies such as fertilizer critical for achieving food security. Yet, the rate of increase in fertilizer use has been substantially lower in Africa than in Asia and Latin America (Byerlee, 1997). Similar observations are also made by Ariga et al. (2006).

Ethiopia's agricultural sector accounts for about 40 percent of national Gross Domestic Product (GDP), 90 percent of exports, and 85 percent of employment. The majority (90 percent) of the poor rely on agriculture for their livelihood, mainly on crop and livestock production. In 2007, 70 percent of all land under crops was used for cereal production (CSA, 2009).

Even if agriculture is the most important sector in the country's economy, Ethiopia has experienced food shortages since the 1970s and millions of people have been suffering from hunger. For the last three decades, 
information on the performance of Ethiopian agriculture indicates that there is a gap between food supply and demand and the sector is unable to produce adequate amounts of food to meet the growing human population in the country. As a response to the large gap between food supply and demand, a collaborative agricultural project that follows extension approach was initiated by the Sasakawa Global 2000, in 1993 and applied to different parts of the country through the involvement of the Ethiopian government (CSA, 2009). As part of the federal government, the Oromia Regional State has taken the mandate to implement the project. Thus, the adoption of agricultural technologies attracts considerable attention because it can provide the basis for increasing production and income of the small-scale farmers. But, there was a persistence of low adoption rate in the study area.

Agricultural technologies have the potential to improve the livelihood of farmers in developing countries by increasing the productivity of land and labor. However, the amount of fertilizer applied by most farmers in Ethiopia was below the recommended levels and has not resulted in achieving the intended outcomes until the 1990s in the Ethiopian economy (Belay, 2003).

Studies on agricultural technologies have been mainly concerned with factors influencing adoption of new technologies but till the present emphases is not given to factors affecting the intensity use of fertilizer (Sunding and Zilberman, 2001).Only few have investigated reasons why farmers applied low rate of technology (Akililu, 2007).

In the study area, it was found out that farmers did not adopt the complete package of practices recommended by the research system. Essentially, the observed failure of farmers to recognize and fully put the recommended production package into practice could be ascribed to various factors which appeared to have some bearing on the farmers' decision to adopt the improved agricultural technologies.

Information from the District Agricultural and Rural Development office recently revealed that about $37 \%$ of the total householders in the district are adopters of fertilizer and the remaining $63 \%$ are non-adopters. They also indicated that the most serious constraints faced by farmers for not adopting the technology was limited by supply of fertilizer technology, lack of awareness about the importance of fertilizer, lack of knowledge and capacity, lack of sustain training on the adoption of agricultural technology program, inadequate cash or credit for purchase of inputs which were the major factors resulting in low productivity of the crop in the study area. (Kenea et al., 2000).

Hence, technology adoption by smallholder farmers was influenced by numerous factors. Factors that influence adoption of fertilizers were not assessed and well perceived. Also the rate and intensity of this technology adoption was not well known in the study area. The overall objective of this study was to analyze factors that affect the smallholder farmers' adoption of fertilizer in Guto Gida District. Specifically it analyzes factors that determine the adoption of fertilizer by small householder farmers and examine factors that influence the intensity of fertilizer use by small householder farmers in the district.

\section{MATERIALS AND METHODS \\ Description of the Study Area}

Guto Gidda is the district found in east Wollega zone. It is located at about 331 kilometes distance from Addis Ababa to the western direction possessing a total area of $901.80 \mathrm{~km}^{2}$. It is bordered with Sibu Sire and Wayyu Tuka in the east, Sasiga, Digga and Benshengul Gumuz in the west, Gidda Ayana, Abe Dongoro and Gudaya Bila in the north and Wayyu Tuqa and Leka Dulecha to the south. It is divided in to $\mathbf{2 1}$ farmers associations.

This district is divided in to three distinct geographical areas with different proportions; namely the high land 0.26 percent which is very small part of the district, midland 46.74 percent and the low land 53 percent. The district has an altitude that lies within elevation of 1,350 to 2,450 meters above sea level.

The district is situated at an altitude above 1350 to 2450 meters above sea level the dominant climatic condition is a sub tropical type. As a result this area is experienced mean annual temperature of slightly greater than $15^{\circ} \mathrm{C}$ and mean annual rainfall of $1600 \mathrm{~mm}$ to 2000 mm (District Agricultural Development Office, 2002 E.C)

Clay loam is among the soil types found in the district i.e. it covers $16.33 \%$ of the total land of the district Sandy soil covers $55,734.60$ hectares of land which is about $23.06 \%$ of the total land of the district. The other soil type exists in the district is loam soil, dominantly found in the district, which good potentiality for agriculture and covers $42.80 \%$ of the total land of the district (District Agricultural Development Office, 2002 E.C)

\section{Data}

Both primary and secondary data were required to attain the objectives of the study. The study needs a large variety of information that can enable us to know the factors influencing the adoption of fertilizer.

\section{Source of Data}

Primary data were collected by interviewing the target smallholder farmers based on prepared questionnaires on the data of fertilizer adoption. Secondary data were collected from administrative offices, agricultural offices, available documents concerned governmental and nongovernmental offices of the district.

\section{Sampling Procedure and Sample Size}

Potential crop producers PAs (Peasant Associations) in the district were selected based on distance from the center of input supply and district extension expert offices purposely. Taking the time, budget and human resource necessary for the research in to consideration, six PAs were selected from 21 PAs; two from far, two from middle and two from near areas to the district center (Nekemte). From the selected PAs, sample size was calculated by using the formula of Kothari (2004) which was 350. The 350 respondents were selected using systematic random sampling technique taking into account the proportional to size (number of households) and sex from adopters and non adopters using the list of farmers from PAs' leaders, key informants and development agents of the respective rural PA accordingly. 
Table 1: The distribution of the householder farmers in the district.

\begin{tabular}{|c|c|c|c|c|}
\hline \multirow{2}{*}{ No } & \multirow{2}{*}{ Name of PAs } & \multicolumn{2}{|c|}{ Number of head of householders } & \multirow[t]{2}{*}{ Total } \\
\hline & & Male & Female & \\
\hline 1 & Abdeta & 1280 & 91 & 1371 \\
\hline 2 & Arjo & 602 & 50 & 652 \\
\hline 3 & Dune Kane & 530 & 111 & 641 \\
\hline 4 & Eba & 791 & 94 & 885 \\
\hline 5 & Fayinera & 609 & 75 & 684 \\
\hline 6 & Fayisa & 1186 & 221 & 1407 \\
\hline 7 & Gari & 710 & 117 & 827 \\
\hline 8 & Gadisa & 951 & 16 & 1273 \\
\hline 9 & Horo Alaltu & 1172 & 82 & 1254 \\
\hline 10 & Ange Magarsa & 168 & 20 & 188 \\
\hline 11 & Jiregna & 780 & 117 & 897 \\
\hline 12 & Jarso Tolera & 594 & 78 & 672 \\
\hline 13 & Kenafi & 538 & 22 & 560 \\
\hline 14 & Loko & 709 & 113 & 822 \\
\hline 15 & Lugo & 950 & 54 & 1004 \\
\hline 16 & Meti & 712 & 49 & 771 \\
\hline 17 & Mada Jalala & 400 & 10 & 410 \\
\hline 18 & Nagasa & 635 & 69 & 704 \\
\hline 19 & Kajela & 311 & 41 & 352 \\
\hline 20 & Kitesa & 240 & 74 & 314 \\
\hline \multirow[t]{2}{*}{21} & Rural ukke & 809 & 55 & 864 \\
\hline & & & Total & 16,552 \\
\hline
\end{tabular}

(Source: Guto Gidda District Agricultural Development Office, 2004 E.C)

Table 2: Distribution of sampled PAs' households by adoption category and sex.

\begin{tabular}{|c|c|c|c|c|c|c|c|c|c|c|}
\hline \multirow{3}{*}{ No } & \multirow{3}{*}{ PAs } & \multicolumn{9}{|c|}{ HHs number by level of adoption and sex in each PAs. } \\
\hline & & \multicolumn{3}{|c|}{ Adopters } & \multicolumn{3}{|c|}{ Non-adopters } & \multicolumn{3}{|c|}{ Total } \\
\hline & & $\mathbf{M}$ & $\mathbf{F}$ & $\mathbf{T}$ & $\mathbf{M}$ & $\mathbf{F}$ & $\mathbf{T}$ & $\mathbf{M}$ & $\mathbf{F}$ & $\mathbf{T}$ \\
\hline 1 & Gari & 276 & 31 & 307 & 434 & 86 & 520 & 710 & 117 & 827 \\
\hline 2 & Abdeta & 488 & 30 & 518 & 815 & 61 & 876 & 1303 & 91 & 1394 \\
\hline 3 & Uke & 303 & 18 & 321 & 506 & 37 & 543 & 809 & 55 & 864 \\
\hline 4 & Loko & 274 & 31 & 305 & 435 & 82 & 517 & 709 & 113 & 822 \\
\hline 5 & Anger Megersa & 64 & 6 & 70 & 104 & 14 & 118 & 168 & 20 & 188 \\
\hline \multirow[t]{2}{*}{6} & Lugo & 355 & 18 & 373 & 595 & 36 & 631 & 950 & 54 & 1004 \\
\hline & Total & 1,760 & 134 & 1,894 & 2,889 & 316 & 3205 & 4,649 & 450 & 5,099 \\
\hline
\end{tabular}

Table 3: Distribution of sampled households by adoption categories and sex.

\begin{tabular}{|c|c|c|c|c|c|c|c|c|c|c|}
\hline \multirow{3}{*}{ No } & \multirow{3}{*}{ PAs } & \multicolumn{9}{|c|}{ Households } \\
\hline & & \multicolumn{3}{|c|}{ Adopters } & \multicolumn{3}{|c|}{ Non-adopters } & \multicolumn{3}{|c|}{ Total } \\
\hline & & $\mathbf{M}$ & $\mathbf{F}$ & $T$ & $\mathbf{M}$ & $\mathbf{F}$ & $T$ & $\mathbf{M}$ & $\mathbf{F}$ & $T$ \\
\hline 1 & Gari & 18 & 3 & 21 & 30 & 6 & 36 & 48 & 9 & 57 \\
\hline 2 & Abdeta & 34 & 2 & 36 & 56 & 4 & 60 & 90 & 6 & 96 \\
\hline 3 & Uke & 21 & 1 & 22 & 34 & 3 & 37 & 55 & 4 & 59 \\
\hline 4 & Loko & 19 & 2 & 21 & 29 & 6 & 35 & 48 & 8 & 56 \\
\hline 5 & Anger Megersa & 4 & 1 & 5 & 7 & 1 & 8 & 11 & 2 & 13 \\
\hline \multirow[t]{2}{*}{6} & Lugo & 24 & 1 & 25 & 41 & 3 & 44 & 65 & 4 & 69 \\
\hline & Total & 120 & 10 & 130 & 197 & 23 & 220 & 317 & 33 & 350 \\
\hline
\end{tabular}




\section{Method of Data Collection}

To generate both qualitative and quantitative data, smallholder farmers of the area were interviewed using structured questionnaires. The questionnaires for the survey of households included data on household characteristics, farm characteristics, household economic variables and institutional variables from sample respondents. Also, there were informal group discussions with target farmers.

The data were collected by enumerators (two diploma holders) after they trained for two days. The questionnaires were translated into local language, for easy understanding by respondents in the main survey area.

As the study is pioneer to the area, there were a continuous review of literature and collection of secondary data from different organizations including administrative office and agriculture office in the area to enrich the study. Moreover, qualitative and quantitative data were sought from official documents on the area of concern. In depth interviews were undertaken with different groups of people during group discussion.

\section{Data Analysis}

Descriptive statistics were used to analyze data by using mean, percentage, standard deviation, Chi-square test and t-test. It provides a summary statistics related to variables of interest. Chi-square test and an independent sample t-test were used to identify variables that vary significantly between adopters and non-adopter. The chisquare test was conducted to compare some qualitative characteristics of the adopters and non-adopters. The ttest was run to observe if there is any statistically significant difference between the mean of the respective adopter and non adopter categories with respect to continuous variables.

\section{Econometric analysis}

In order to achieve the specified objectives and answer the questions set, this study was used econometric models. Adoption behavior models range from simple relationships to complex multivariate analyses. Logit, probit and Tobit models are commonly used to identify factors that influence decisions to use a new technology (Makokha et al., 2001). Logit and probit models are appropriate when the dependent variable is dichotomous $(0,1)$, while the Tobit model is useful for continuous values that are censored at or below zero (Anley et al., 2007).

Probit Model: Following Rahm and Huffman (1984), denote a technology index by $t$, where $t$ is equal to 1 for the old technology and 2 for a new or different technology; moreover, a linear relationship is postulated for the $\mathrm{i}^{\text {th }}$ firm between the utility derived from the $i^{\text {th }}$ technology and $a$ vector of observed firm specific characteristics Xi (such as, farm size) and a zero mean random disturbance term ei:

$$
\text { (1) Uti }=\text { Xiat }+e_{t i}, \quad t=1,2 ; \quad i=1 \ldots n \text {. }
$$

Farm operators are assumed to choose the technology that gives them the largest utility. Thus, the $i^{\text {th }}$ firm adopts the new technology if $U_{2 i}$ exceeds $U_{1 i}$, and thus the qualitative variable $\mathrm{Di}$ indexes the adoption decision:

(2) $D_{t}=\left\{\begin{array}{l}1 \text { if } u_{1 i}<u_{2 i} \text {, new technology is adopted } \\ 0 \text { if } u_{1 i} \geq u_{2 i} \text {, old technology is continued }\end{array}\right.$
The probability that $\mathrm{Di}$ is equal to one can be expressed as a function of firm-specific characteristics:

$$
\text { (3) } \begin{aligned}
\mathrm{Pi} & =\operatorname{Pr}(D i=1)=\operatorname{Pr}\left(\mathrm{U}_{1 \mathrm{i}}<\mathrm{U}_{2 \mathrm{i}}\right) \\
& =\operatorname{Pr}\left(\mathrm{Xi \alpha}_{1}+\mathrm{e}_{1 \mathrm{i}}<\mathrm{Xi \alpha _{2 }}+\mathrm{e}_{2 \mathrm{i}}\right) \\
& =\operatorname{Pr}\left[\mathrm{e}_{1 \mathrm{i}}-\mathrm{e}_{2 \mathrm{i}}<\mathrm{Xi}\left(\alpha_{2}-\alpha_{1}\right)\right] \\
& =\operatorname{Pr}(\mu \mathrm{i}<\mathrm{Xi} \beta)=\mathrm{F}(\mathrm{Xi} \beta)
\end{aligned}
$$

Where; $\operatorname{Pr}()=$. a probability function $\mu \mathrm{i}=\mathrm{e}_{1 \mathrm{i}}-\mathrm{e}_{2 \mathrm{i}}$ is a random disturbance term $\beta=\alpha 2-\alpha 1$ is a vector of parameters to be estimated $F(X i \beta)=$ is the cumulative distribution function for $\mu \mathrm{i}$ evaluated at $\mathrm{Xi}$.

The probability of the $i^{\text {th }}$ firm adopting the new technology is thus the probability that the utility of the old technology is less than the utility of the new technology or the cumulative distribution function $F$ evaluated at $X i \beta$. And the exact distribution for $F$ depends on the $n$ distribution of the random term $\mu \mathrm{i}=\mathrm{e}_{1 \mathrm{i}}-\mathrm{e}_{2 \mathrm{i}}$.

The researcher therefore applied a probit model to achieve the first objective. The dependent variable; adopt, is specified as a function of exogenous variables that are reasonably supposed to enter into the model.

Verbeek, (2004) has expressed random effect Probit model as:

$$
\begin{aligned}
& \text { Yit }{ }^{*}=X i t \beta+\text { Uit } \\
& \text { Yit }=1 \text { if Yit }{ }^{*}>0 \\
& \text { Yit }=0 \text { if Yit }{ }^{*} \leq 0
\end{aligned}
$$

Where; Uit is an error term with mean zero and unit variance, independent of $\left(\mathrm{Xi}_{1} \ldots \mathrm{Xi}_{\mathrm{t}}\right)$

Yit * is unobservable latent variable $=1$ if the farmer adopt fertilizer; 0 otherwise

\section{Xit is the explanatory variables \\ $\beta$ unknown regression parameters; and}

The model has been specified with household random effect to control for unobserved heterogeneity. In terms of estimation method, Wooldridge, (2009) indicated that for estimating a limited dependent variable models, maximum likelihood methods are indispensable.

Tobit Model: The second econometric analysis used in this paper was the quantity of fertilizer per hectare used as the dependent variable. According to Verbeek, (2004) when the dependent variable is zero for a substantial part of the population but positive for the remaining observation, the Tobit model is appropriate and most commonly used.

The intensity of use of fertilizer was analyzed by replacing the dependent dummy variable given in the first model equation with the intensity of use of fertilizer in $\mathrm{kg} / \mathrm{ha}$. Fertilizer is measured by its weight. It is measured in units $(\mathrm{kg})$ per unit of land (hectare) to examine intensity of fertilizer use. Here the model would also be specified with household random effects to control for unobserved heterogeneity.

The Tobit model is a censored regression model. Observations on the Latent variable $Y$ are missing (or censored) if Yit* is below a certain threshold level. One of the applications of the Tobit model is when the dependent variable (in our case quantity of fertilizer use per hectare) is zero for some individuals in the sample. Verbeek, 
(2004) has given the random effect Tobit model in the form of:

$$
\begin{array}{ll}
\text { Where; } & \text { Yit }^{*}=\beta_{i} X i t+\varepsilon i t \\
& \text { Yit }=\text { Yit }^{*} \text { if } \text { Yit }^{\star}>0 \\
& \text { Yit }=0 \quad \text { if } \text { Yit }^{*} \leq 0
\end{array}
$$

Yit $^{*}$ is the latent variable, $\beta i$ is the vector of parameters to be estimated, Xit is the vector of explanatory variables to be used in the analysis and zit is the disturbance term.

\section{RESULTS AND DISCUSSIONS}

In this part, the results of the Probit and Tobit model are presented and discussed to observe the relative influence of different household's characteristic and demographic variables, farm characteristics, household economic variables and institutional factors on adoption

\begin{tabular}{|c|c|c|c|c|}
\hline $\begin{array}{l}\text { Independent } \\
\text { Variables }\end{array}$ & $\begin{array}{c}\begin{array}{c}\text { Coefficients } \\
\text { (dy/dx) }\end{array} \\
\end{array}$ & $\begin{array}{l}\text { Robust } \\
\text { Std. Err. }\end{array}$ & $\mathbf{z}$ & $P>Z$ \\
\hline Sex & -0.0300279 & 0.2562753 & -0.35 & 0.726 \\
\hline Education & $0.1057111^{*}$ & 0.0833741 & 3.87 & 0.000 \\
\hline Farm experience & 0.0000222 & 0.0101135 & 0.01 & 0.995 \\
\hline Association participation & $0.1895367^{*}$ & 0.2679906 & 2.65 & 0.008 \\
\hline Family size & $0.0594736^{*}$ & 0.0451298 & 4.03 & 0.000 \\
\hline Landholding & 0.0212747 & 0.1023209 & 0.64 & 0.525 \\
\hline Extension contact & $0.1594577^{\star \star}$ & 0.2224012 & 2.19 & 0.028 \\
\hline Access to information & $0.183221^{*}$ & 0.1704847 & 3.28 & 0.001 \\
\hline Access to credit & $0.2613529^{*}$ & 0.1688078 & 4.73 & 0.000 \\
\hline Distance to market & $-0.0027567^{* *}$ & 0.0038911 & -2.16 & 0.030 \\
\hline Farm income & $0.0000139^{*}$ & 0.0000137 & 3.10 & 0.002 \\
\hline Off-farm activity & $0.3617669^{*}$ & 0.2169184 & 5.52 & 0.000 \\
\hline Lives tocks & $-0.0680299^{* *}$ & 0.0913559 & -2.28 & 0.023 \\
\hline Constant & -2.813067 & 0.4775601 & -5.89 & 0.000 \\
\hline Number of obs. & 350 & Wald chi2(13) & $=107.34$ & \\
\hline Prob > chi2 & 0.000 & Pseudo R2 & $=0.4373$ & \\
\hline Log pseudo likelihood = & -129.93451 & & & \\
\hline
\end{tabular}
and intensity adoption of fertilizer technology.

Table 4: Estimated results of Probit model of fertilizer adoption

The computed marginal coefficient of the probit regression result indicated that an education of the household head would increase the probability of adoption of fertilizer technology by $10.57 \%$, which was statistically significant at $1 \%$ significant level. The estimated coefficient for this variable shows that there was a positive relation between adoption and education level of the head of householders in the study area (table 3). Educated farmers can better process information more rapidly than otherwise (Schultz, 1975).

The estimated marginal coefficient result for this variable was found to be positive and significantly influencing adoption of fertilizer technology at $1 \%$ significant level. Analysis of probit regression marginal coefficient indicated that a unit increases in the household size increases the probability of adoption of fertilizer technology by $5.95 \%$, ceteris paribus. This indicated that the larger the family size of household the more labor force exist, who are engage in agricultural production which increases the demand for fertilizer technology. Mulugeta Mekuria (1994), in his study of the adoption of chemical fertilizer in wheat production in the southeastern highlands of Ethiopia, has shown that family size could have both a positive and significant effect on fertilizer adoption, which supports the current study.

A marginal effect coefficient of probit result depicted that getting extension service increases the probability of adoption of fertilizer by $15.95 \%$ at $5 \%$ significant level having positive impact on the adoption of fertilizer. This implies that strengthening extension contact has significant contribution on the adoption of fertilizer technology among smallholder farmers in the study area, keeping other variables constant. Empirical results revealed that extension contact has a positive influence on farm households' adoption of new technology (Hailu, 2008), which was in line with the finding of this study.

Analysis of the marginal effect of the Probit model indicated that having information access and access of credit increases the probability of fertilizer adoption by $18.32 \%$ and $26.14 \%$, respectively, they were statistically significant at $1 \%$ significant level. Studies reported by Yishak, (2005) also support this study as access to information has positive relationship with adoption of fertilizer technology.

The estimated marginal effect coefficient of the probit regression model shows a unit increase in farm income increases the probability of adoption of fertilizer technology by $0.0014 \%$. This result indicates that households with relatively higher farm income are expected to better adopt the technology than their counterparts, keeping the effects of all other variables at constant. Farm income is expected to positively influence fertilizer adoption which is in line with the findings of (Leggese, 1998). 
Table 5: Factors determining the intensity use of fertilizer (Tobit regression).

\begin{tabular}{|c|c|c|c|c|}
\hline $\begin{array}{l}\text { Explanatory } \\
\text { variables }\end{array}$ & $\begin{array}{l}\text { Coefficients } \\
(\mathrm{dy} / \mathrm{dx})\end{array}$ & $\begin{array}{l}\text { Robust } \\
\text { Std.Err. }\end{array}$ & $\mathbf{t}$ & $P>t$ \\
\hline Sex & 7.012014 & 8.089769 & 0.87 & 0.388 \\
\hline Farm experience & $0.6192146^{*}$ & 0.189501 & 3.27 & 0.001 \\
\hline Association participation & 0.8549858 & 8.291759 & 0.10 & 0.918 \\
\hline Family size & $-5.287599^{\star}$ & 1.045879 & -5.06 & 0.000 \\
\hline landholding & $4.462161^{*}$ & 1.477798 & 3.02 & 0.003 \\
\hline Access to information & $28.11874^{*}$ & 4.466006 & 6.30 & 0.000 \\
\hline Distance to market & -0.0670377 & 0.105628 & -0.63 & 0.527 \\
\hline Farm income & 0.0001665 & 0.000325 & 0.51 & 0.609 \\
\hline Off-farm activity & $14.43652^{* *}$ & 6.186238 & 2.33 & 0.021 \\
\hline Livestock size & $-4.314706^{*}$ & 1.547937 & -2.79 & 0.006 \\
\hline Constant & 52.33662 & 12.17632 & 4.30 & 0.000 \\
\hline /sigma & 22.40374 & 1.304814 & & \\
\hline Number of obs. & $=130$ & \multicolumn{3}{|c|}{ Prob $>F=0.000$} \\
\hline$F(10,120)$ & $=21.63$ & \multicolumn{3}{|c|}{ Pseudo R2 = 0.0562} \\
\hline Log pseudo likelihood & $=-585.52626$ & & & \\
\hline
\end{tabular}

(Source: model output, 2013)

Experience would improve the farmer's skill on the use of fertilize technology. More experienced farmers apply more fertilizer on their farm land to increase the production and productivity to satisfy the food need of their family. The estimated coefficient of marginal effect of this variable indicates that a one year increases in households' farm experience would increase the intensity use of fertilizer by $0.62 \mathrm{Kg} / \mathrm{ha}$ and had positive and significant impact on the intensity use of fertilizer at $5 \%$ significant level in the study area, assuming that the effects of other things are remain constant. This implies that farmers with higher farm experience appear to have often full information and better knowledge and are able to evaluate the advantage of the technology in question. The study conducted by Chilot et al., (1996) consistent with the recent study.

Total family size in this study refers to the number of members who are currently living within the family. Analysis of marginal effect shows having extra unit of family size decreases the intensity use of fertilizer technology by $5.29 \mathrm{Kg} / \mathrm{ha}$, keeping others constant. This implies that as the number of household family size increases, their demand towards consumptions, clothes and other needs also increases, which in turn, reduces the application rate of fertilizer by smallholder farmers in the study area. The income generated from different activities might be spent on such situations rather than spending on the purchase of fertilizer technology. Based on this assumption, this variable has a negative relationship with intensity use of fertilizer technology, which was confirmed by the study conducted John et al., (2009).

Land is one of the major and the key asset for farmers everywhere. Thus, the application rate of fertilizer made by any household is basically and highly influenced by their land holding size. From the Tobit regression model, its marginal effect coefficient indicates that a unit increase in landholding size increases the intensity use of fertilizer technology by $4.46 \mathrm{Kg} / \mathrm{ha}$, which was statistically significant at $1 \%$ significant level, supposing that other variables were remain constant. This implies that a household who holds a greater farm land is more likely to apply more fertilizer to enhance their production and productivity than a household who holds less farm land. Thus, landholding has a positive relationship with the intensity use of fertilizer technology.

An access to information through mass media on any agricultural programs was expected to influence a farmer's awareness and, therefore, increases the application rate of fertilizer. Hence, analysis of the marginal effect of the Tobit model indicates that having information access increases the intensity use of fertilizer by $28.12 \mathrm{Kg} / \mathrm{ha}$ and the variable had positive correlation with intensity use of fertilizer, which was statistically significant at $1 \%$ significant level, ceteris paribus. This implies that adequate information was crucial in influencing the intensity use of fertilizer technology among farmers in the study area. Mass media plays the greatest role in provision of information in the shortest possible time over large area of coverage.

Participation in off-farm activities is believed to have a bearing on the income of households. Additional income earned through participation in these activities improves farmers' financial capacity and increases the ability to adopt new technology. Thus, participation in off-farm activities had a positive influence on the intensity of fertilizer use technology. The coefficient of marginal effect of Tobit result indicates that participation in off-farm activities increases the intensity use of fertilizer by $14.44 \mathrm{Kg} / \mathrm{ha}$ in the study area, keeping the value of all other variable at stagnant. This implies the need to give emphasis to participate in off-farm activity is to get extra income that can increase the intensity use of fertilizer when compared with those household farmers who are not participated in such activity. 
In the study area, farmers in addition to other farming practices they rear livestock. The estimated result of marginal effect of Tobit regression model indicates that having a unit of livestock decreases the intensity use of fertilizer by $4.32 \mathrm{Kg} / \mathrm{ha}$. The result shows that the variable has negative impact on the application rate of fertilizer and statistically significant at $1 \%$ significant level, other things remain fixed. This depicts that the householders those who have more livestock apply less amount of fertilizer on their farm land than those who have low livestock. This might be because of the farmers having large livestock can use livestock's manure, which reduce the application rate of the fertilizer.

\section{CONCLUSIONS}

Fertilizer is considered as one of the most important inputs for the achievement of increased agricultural productivity and food security in Ethiopia. However, the small household farmers were experienced with low production and productivity, which are highly associated with limited supply of fertilizer technology, lack of awareness about the importance of fertilizer, lack of knowledge and capacity, lack of sustain training on the use fertilizer, inadequate cash or credit for purchase of inputs. These were the major factors resulting in low productivity of the crop in the study area.

Accordingly, the econometric analysis Probit model regression has revealed that variables like education of the head of the household, association participation, family size, extension contact, access to information, access to credit and farm incomes were positively and significantly determined the adoption of fertilizer at a standard level of significance.

Furthermore, from the Tobit regression result, it was highlighted that the significant determinants of intensity use of fertilizer includes landholding size, access to information, off-farm activity and farm experience were found to be the major and the significant ones in the study area.

Based on the findings of this study, the following points are recommended to improve farmers' adoption of fertilizer technology package so as to enhance their production and productivity.

Credit is essential to enable small farmers to purchase production inputs like fertilizer, seed of improved maize varieties, pesticides, etc. In the country as a whole, the cost of fertilizer and other inputs are often beyond the purchasing ability of farmers. Therefore, policy makers should made further efforts in strengthening financial institutions like micro finance and other arrangements that can relax farmers' liquidity constraints and help them to afford these technological inputs. Another way of relaxing credit constraint would be to improve access to viable offfarm income generating activities.

In the study area, it was observed that education of household heads was positively related to fertilizer adoption. Hence, any agricultural policy that would educate people through proper agricultural extension services would definitely lead to increase adoption of fertilizer by farmers' thereby increasing agricultural productivity. Therefore, it is possible to recommend that the regional government should have a prime responsibility to keep on provision of education in these areas and others so that farmers can use the available inputs more efficiently under the existing technology.

Extension service was found to have a strong relation with adoption of fertilizer technology package as it enhances ability to acquire and use information required for production. Therefore, emphasis has to be given towards strengthening farmers' knowledge on adoption of fertilizer by providing continues training to increase awareness of the farmers in the study area towards the benefits of using fertilizer.

To increase the interaction between farmers and development agents and to promote technology transfer, more development agents must be recruited. The program should provide better transport facilities to development agents in order to increase their capacity to travel within their mandated area. In addition, frequent training must be organized for development agents and supervisors about existing and newly developed improved technologies and new methods of agricultural practices. This is expected to develop the confidence of the agents to transmit appropriate and useful information to farmers.

\section{REFERENCES}

Aklilu, B. (2007). The Diffusion of Fertilizer in Ethiopia: Pattern, Determinants, and Implications. The Journal of Developing Areas 387-399.

Anley, Y., Bogale, A. and Haile-Gabriel, A. (2007). Adoption decision and use intensity of soil and water conservation measures by smallholder subsistence farmers in Dedo district, Western Ethiopia. Land Degradation and Development 18(3): 289-302.

Ariga, J., Jayne, T.S. and Nyoro, J. (2006). Factors Driving the Growth in Fertilizer Consumption in Kenya, 1990 - 2005: Sustaining the Momentum in Kenya and Lessons for Broader Replicability in sub-Saharan Africa. Tegemeo Working Paper 24/2006. Nairobi: Tegemeo Institute, Egerton University

Belay, K. (2003). Agricultural Extension in Ethiopia: The Case of Participatory Demonstration and Training Extension System. Journal of social Development in Africa 18(1): 49-83

Byerlee Derek (1997). Africa's Emerging Maize Revolution. Boulder, CO: Lynne Rienner Publishers.

Chilot Yirga., Shampiro, B.I. and Mulat Demeke. (1996). Factors Influencing doption of new weat technologies in Wolmera and Addis Alem Areas of Ethiopia. Ethiopian Journal of Agricultural Economics 1: 63-83

CSA (2009). Agricultural Sample Survey 2008/2009 E.C. Report on area and production for major crops (private peasant holdings). Statistical bulletin Addis

Duflo, E., Kremer, M. and Robinson, J. (2006). Understanding Technology Adoption: Fertilizer in Western Kenya: Preliminary Results from Field Experiments. Cambridge.

Hailu Beyene (2008). Adoption of improved teff and wheat production in crop livestock mixed system in northern and western shewa zones of Ethiopia Ph. D. Thesis

John O., Geophrey S., and Mary Mathenge (2009). Agricultural Technology Adoption: A Panel Analysis of Smallholder Farmers' Fertilizer use in Kenya. 
Kenea Yadeta., Setotaw Ferede., Hailemariam, T.W. and Fasil, K.W (2000). On-farm analysis of durum wheat production technologies in central Ethiopia." In: CIMMMYT.

Kothari (2004). Former Principal, College of Commerce University of Rajasthan, Jaipur (India).

Legese Daddi (1998). Adoption and Diffusion of Agricultural Technologies: The Case of East and West Shoa Zones, Ethiopia, A Thesis Submitted to the University of Manchester for the degree of Doctor of Philosophy in the Faculty of Economics and Social Studies, School of Economic Studies.

Makokha, S., Kimani, S., Mwangi, W., Verkuijl, H., Musembi, F. (2001). Determinants of fertilizer and manure use in maize production in Kambu district, Kenya.

Mulugeta Mekuria (1994). An Economic Analysis of Smallholder Wheat Production and Technology Adoption in the Southeastern Highlands of Ethiopia. Ph.D. Thesis.

Rahm, M.R. and Huffman, W.E. (1984). The adoption of reduced tillage: The role of human capital and other variables. American Journal of Agricultural Economics 66: 405-413.

Schultz, T.W. (1975). The Value of the Ability to Deal with Disequilibrium. Journal of Economic Literature 13: 827-846.

Sunding, D., Zilberman, D. (2001). The agricultural innovation process: research and technology adoption in a changing agricultural sector. In: Gardner, B.L., Rausser, G.C. (Eds.) Volume 1A Agricultural Production. Elsevier, New York.

Verbeek, M., (2004). A Guide to Modern Econometrics" 2nd ed., Erasmus University Rotterdam, John Wily and Sons Ltd., England

Wooldridge, J.M. (2009). Introductory econometrics: A modern approach, South-Western Pub.

World Bank (2008). World Development Report 2008, Agriculture for Development. The World Bank. Washington, DC.

Yishak Gecho (2005). Determinants of Adoption of Improved Maize Technology in Damot Gale Woreda, Wolaita, Ethiopia. MSc Thesis. Alemaya University. 